\title{
TECHNOLOGICAL DEVELOPMENT OF PROTEIN-RICH CONCENTRATES USING SOYBEAN AND MEAT BY-PRODUCTS FOR NUTRITION IN EXTREME CONDITIONS
}

\author{
Tatiana K. Kalenik ${ }^{1}$, Rui Costa ${ }^{2 凶}$, Elena V. Motkina ${ }^{1}$, Tamara A. Kosenko ${ }^{1}$, \\ Olga V. Skripko ${ }^{3}$, Irina A. Kadnikova ${ }^{1,4}$ \\ ${ }^{1}$ School of Biomedicine, Far Eastern Federal University (FEFU) \\ Building 25, FEFU Campus, Russian Island, Vladivostok, Russia \\ ${ }^{2}$ Research Centre for Natural Resources, Environment and Society (CERNAS), College of Agriculture of the Polytechnic Institute \\ of Coimbra \\ Bencanta, 3045-601 Coimbra, Portugal \\ ${ }^{3}$ Federal State Budget Scientific Institution (FSBSI) Russian Scientific Research Institute of Soya \\ Ignatyevskoye 19, 675027 Blagoveschensk, Russia \\ ${ }^{4}$ Federal State Budget Scientific Institution (FSBSI) Pacific Scientific Research Fisheries Center \\ Shevchenko lane 4, 690091 Vladivostok, Russia
}

\begin{abstract}
Background. There is a need to develop new foods for participants of expeditions in extreme conditions, which must be self-sufficient. These foods should be light to carry, with a long shelf life, tasty and with high nutrient density. Currently, protein sources are limited mainly to dried and canned meat. In this work, a protein-rich dried concentrate suitable for extreme expeditions was developed using soya, tomato, milk whey and meat by-products.

Materials and methods. Protein concentrates were developed using minced beef liver and heart, dehydrated and mixed with a soya protein-lycopene coagulate (SPLC) obtained from a solution prepared with germinated soybeans and mixed with tomato paste in milk whey, and finally dried. The technological parameters of pressing SPLC and of drying the protein concentrate were optimized using response surface methodology. Results. The optimized technological parameters to prepare the protein concentrates were obtained, with 70:30 being the ideal ratio of minced meat to SPLC. The developed protein concentrates are characterized by a high calorific value of $376 \mathrm{kcal} / 100 \mathrm{~g}$ of dry product, with a water content of $98 \mathrm{~g} \cdot \mathrm{kg}^{-1}$, and $641-644 \mathrm{~g} \cdot \mathrm{kg}^{-1}$ of proteins. The essential amino acid indices are 100, with minimum essential amino acid content constituting $100-128 \%$ of the FAO standard, depending on the raw meat used. These concentrates are also rich in micronutrients such as $\beta$-carotene and vitamin $C$.

Conclusion. Analysis of the nutrient content showed that these non-perishable concentrates present a high nutritional value and complement other widely available vegetable concentrates to prepare a two-course meal. The soups and porridges prepared with these concentrates can be classified as functional foods, and comply with army requirements applicable to food products for extreme conditions.
\end{abstract}

Keywords: protein concentrate, soya, meat, lycopene, extreme conditions, nutritional value 


\section{INTRODUCTION}

At present, the problems of nutrition and health are closely interrelated and are the basis of primary and secondary prevention of various alimentary diseases. Food, unlike other environmental factors, is a multicomponent factor affecting the function and tropism of tissues, organs and systems of the body towards their intensification or atrophy, depending on the food amount and composition (Berdanier et al., 2013). Vital activities of the modern human era are related to high mobility. Today, different expeditions are actively arranged and conducted in many hard-to-reach areas of the world. The Arctic and Antarctic are being intensely developed, excavations are being carried out in the mountains, forests and deserts, and various investigations are being carried out in the seas and oceans. Space travel is another extreme condition, though not a common subject of research. All these activities are related to extreme conditions in which participants must be self-sufficient, which inevitably result in physiological stress.

Numerous investigations demonstrate that the balance between the body's energy output and input is disturbed under physiological stress in extreme conditions (Marriott and Carlson, 1996; Selvamurthy and Singh, 2003). For example, in high mountainous regions, cold combined with hypoxia leads to a loss of appetite (Srivastava et al., 1992). It has particularly been pointed out that the consumption of proteins, fats and vitamins, in particular ascorbic acid, carotenoids, thiamine, riboflavin, and pyridoxamine increase under such conditions (UD6-81-3E, 2011). The ingestion of food with the adequate composition for the appropriate functional needs - e.g. with tryptophan before sleeping - has also been suggested (Srivastava et al., 1992). Research and experience have shown that in such conditions it is essential to eat physiologically balanced, high-quality products. Apart from being highly calorific, especially for nutrition in the cold (Poos et al., 1999), tasty (Flandrin and Montanari, 1999), appropriate for the human metabolism during a specific vital activity in extreme situations, such products should be suitable for long-term storage, highly digestible and of a lower weight and volume than regular products. Such products should be readily available for use by, amongst others, soldiers, athletes and geologists.
Food for extreme conditions is mainly based on concentrates, for example, soups, porridge, buckwheat pudding and other cereal puddings. These are dry product mixtures that differ from traditional foods due to a low moisture content, high concentrations of nutrients, as well as long shelf life. Food concentrates for special purposes, such as consumption in extreme conditions, must provide a good taste, high calorific content and a high satiety index (Holt et al., 1995). The increased interest in using food concentrates in extreme conditions have led to several patents in the Russian Federation (russianpatents.com).

Nowadays, the main protein ingredient in food concentrate recipes is dried meat or minced meat, usually beef or chicken, used either for mountain sports (JAWAFOOD, n.d.) or the army (Marriott and Carlson, 1996). Minced meats currently used in the food concentrate industry do not keep their shape in the proper way and have an unattractive appearance. To improve these factors, the authors suggest the use of by-products of the first category, in particular, beef liver and heart, and ingredients such as soybean, tomatoes, and milk whey.

To the authors' knowledge, research on food for extreme conditions is scarce or unpublished, which justifies the subject of the present work. The purpose of this work was to develop new protein concentrates, for formulations of food concentrates for diets in extreme conditions using soybean and meat by-products and to optimize its technological parameters.

\section{MATERIAL AND METHODS}

\section{Food materials}

All food materials comply with the Russian Federation Standards (Standarty..., 2016). Soybean seeds of the "Lazurnaya" grade of the Far Eastern selection, obtained from the laboratory of the Russian Scientific Research Institute of Soya (Blagoveschensk, Russian Federation), comply with the requirements of GOST 17109-88 (1995). A soybean protein dispersion was prepared from these seeds and water. Tomato paste with $300 \mathrm{~g} \cdot \mathrm{kg}^{-1}$ of dry matter content was prepared from fresh tomatoes, complying with the requirements of GOST 3343-89 (2008). Milk whey was obtained during curd production, follow the requirements of the GOST R 53438 (2009). Minced 
meat was obtained from frozen by-products (beef heart and liver) conforming to the requirements of the standard GOST 32244 (2013), purchased in a local supermarket.

\section{Preparation of the ingredients to produce the food concentrates}

Soybean ingredient. The soybean seeds were germinated, crushed and subjected to extraction. Germination was achieved over $120 \mathrm{~h}$ at $26^{\circ} \mathrm{C}$ until shoots reached 4.0-5.0 cm. Germinated soybeans were washed, soaked in water for swelling for 8 hours, then washed and milled in water at a proportion of 1:6 (soybeans: water), heated to $95-100^{\circ} \mathrm{C}$ for $1-2 \mathrm{~min}-$ utes and, finally, separated into the soluble (suspension) and insoluble fractions. The suspension was the soybean ingredient used in the next stages.

Tomato paste in milk whey. The solution of the tomato paste in milk whey was selected as a structure agent and coagulant for the soya protein dispersion (soybean ingredient), to obtain fewer whey losses. The coagulant was prepared with milk whey mixed with tomato paste (2:1) to achieve a dry matter content of $125-150 \mathrm{~g} \cdot \mathrm{kg}^{-1}$ and $\mathrm{pH}$ of 4.45-4.5. Tomato paste refers to the concentrated tomato product which is obtained by boiling the crushed mass. The concentration of solids of the tomato paste tested were $250,300,350$ and $400 \mathrm{~g} \cdot \mathrm{kg}^{-1}$, with the $300 \mathrm{~g} \cdot \mathrm{kg}^{-1}$ concentration giving the desired results.

Soybean protein-lycopene coagulate (SPLC). The soybean suspension was subject to a thermal acid coagulation with tomato paste in milk whey by heating it to $55-60^{\circ} \mathrm{C}$ during $10-12 \mathrm{~min}$, after which the coagulant was added and then the clot was separated from the whey (see flux diagram at the top right of Figure 1). The final result was a pink soybean protein-lycopene coagulate. SLPC was separated from the whey by in a pneumatic press for cheese IPKS-058-01 (N) ("ELF 4M Trading House", Ryazan). Since the quality of the granular minced meat by-products depends on the moisture content of the SPLC, this operation was optimized with the main factors being varied as follows (Table 1): initial coagulum moisture content between $600-800$ $\mathrm{g} \cdot \mathrm{kg}^{-1}$, pressure during compression between $0.5-1.5$ $\mathrm{MPa}$ and compression time between 10-30 minutes.
Minced meat. Beef liver and heart were blanched in water at a temperature between $90-100^{\circ} \mathrm{C}$ for $15-20$ minutes and drained for 3-5 min at a temperature between $18-20^{\circ} \mathrm{C}$ until water from the surface of the offal pieces had evaporated, to achieve a reduction of the water content from $600-700 \mathrm{~g} \cdot \mathrm{kg}^{-1}$ to $400-420 \mathrm{~g} \cdot \mathrm{kg}^{-1}$. Then the meat was ground (DIP-05, Machcomplect, Moscow) into $2-3 \mathrm{~mm}$ particles. The flux diagram is presented at the top left of Figure 1.

\section{Preparation of the protein concentrate: mixing minced meat with SPLC}

The final protein concentrate was obtained by mixing minced meat with SPLC, with ratios varying from 90:10 to 50:50 in the mixer BWL-50/BWL-100 (Harbin Golden Happiness Commercial Machinery, Harbin). Each mixture was shaped into granules with a diameter of 2-3 $\mathrm{mm}$ by passing the mass through a grinder DIP-05 (Machcomplect, Moscow). Obtained granules of protein concentrates were dried by convective air drying at $110^{\circ} \mathrm{C}$ for $30 \mathrm{~min}$ in the infrared electric oven Universal-SD-4 ("Drying case", Saint Petersburg) to achieve a water content of $98 \mathrm{~g} \cdot \mathrm{kg}^{-1}$ (see flux diagram at the bottom of Figure 1).

This drying step was optimized in relation to the organoleptic evaluation of the main factors, varying as follows (Table 2): drying temperature between 30$40^{\circ} \mathrm{C}$, drying time adjusted from $120-180$ minutes, and the mass fraction of the SPLC between $300-400 \mathrm{~g} \cdot \mathrm{kg}^{-1}$.

\section{Preparation of the food concentrates}

The developed protein concentrates were used in the preparation of mixtures of food concentrates, namely, the 4 model recipes of soups with various cereals ( 150 $\mathrm{g} \cdot \mathrm{kg}^{-1}$ of protein concentrate) and the 4 model recipes of porridges (100 g. $\mathrm{kg}^{-1}$ of protein concentrate). The recipes are presented in Table 3, prepared according to recommendations for the army (FSB, 2011).

\section{Nutritional composition}

The main nutrients of soybean, tomato paste solution in milk whey, SPLC, minced meat and products prepared with it were determined by standard methods. To study the conformity of the nutrients and the calorific value of the rations, descriptions of military rations used in cold-weather operations presented by FSB (2011) were consulted. 




Fig. 1. Technological scheme for producing the protein concentrate of dry minced meat by-product with soybean protein-lycopene component: $\mathrm{W}$ - water content, *optimized operation

The composition of soybean seeds - proteins, fats, carbohydrates, moisture, amino acid content, and fibre - was determined by infrared scanner, FOSS NIR System 5000 (Foss Analytical AB, Hogonas, Sweden).
The contents of the analyzed components were calculated with a calibration equation supplied by the company which supplied the NIR. This analysis is in accordance with the standard GOST R 53600 (2009). 
Kalenik, T. K., Costa, R., Motkina, E. V., Kosenko, T. A., Skripko, O. V., Kadnikova, I. A. (2017). Technological development of protein-rich concentrates using soybean and meat by-products for nutrition in extreme conditions. Acta Sci. Pol. Technol. Aliment., 16(3), 255-268. http://dx.doi.org/10.17306/J.AFS.2017.0501

Table 1. The planning matrix and the results of the experiments on studying the dependence of the moisture content of the $\operatorname{SPLC}\left(W_{f}\right)$ with initial coagulum moisture content between $\left(W_{i}\right)$, pressure during compression $(P)$, and compression time $\left(t_{p}\right)$

\begin{tabular}{|c|c|c|c|c|c|c|c|}
\hline \multirow{2}{*}{$\frac{\text { Experiment }}{1}$} & \multicolumn{2}{|c|}{$\mathrm{x}_{1}\left(W_{i}, \mathrm{~g} \cdot \mathrm{kg}^{-1}\right)$} & \multicolumn{2}{|c|}{$\mathrm{x}_{2}(P, \mathrm{MPa})$} & \multicolumn{2}{|c|}{$\mathrm{x}_{3}\left(t_{p}, \min \right)$} & \multirow{2}{*}{$\frac{\mathrm{Y}\left(W_{f}, \mathrm{~g} \cdot \mathrm{kg}^{-1}\right)}{590}$} \\
\hline & -1 & 600 & -1 & 0.5 & +1 & 30 & \\
\hline 2 & +1 & 800 & -1 & 0.5 & -1 & 10 & 640 \\
\hline 3 & -1 & 600 & +1 & 1.5 & -1 & 10 & 520 \\
\hline 4 & +1 & 800 & +1 & 1.5 & +1 & 30 & 530 \\
\hline 5 & -1 & 600 & -1 & 0.5 & -1 & 10 & 620 \\
\hline 6 & +1 & 800 & -1 & 0.5 & +1 & 30 & 590 \\
\hline 7 & -1 & 600 & +1 & 1.5 & +1 & 30 & 500 \\
\hline 8 & +1 & 800 & +1 & 1.5 & -1 & 10 & 620 \\
\hline 9 & -1.215 & 580 & 0 & 1.0 & 0 & 20 & 510 \\
\hline 10 & +1.215 & 820 & 0 & 1.0 & 0 & 20 & 600 \\
\hline 11 & 0 & 700 & -1.215 & 0.4 & 0 & 20 & 620 \\
\hline 12 & 0 & 700 & +1.215 & 1.7 & 0 & 20 & 490 \\
\hline 13 & 0 & 700 & 0 & 1.0 & -1.215 & 8 & 570 \\
\hline 14 & 0 & 700 & 0 & 1.0 & +1.215 & 32 & 490 \\
\hline 15 & 0 & 700 & 0 & 1.0 & 0 & 20 & 500 \\
\hline
\end{tabular}

Table 2. The planning matrix and the results of the experiments on studying the dependence of organoleptic evaluation with drying temperature $(T)$, drying time $\left(t_{d}\right)$ and the mass fraction of the lycopene-protein coagulate $(M)$

\begin{tabular}{|c|c|c|c|c|c|c|c|c|}
\hline \multirow{2}{*}{$\begin{array}{c}\text { Experiment } \\
1\end{array}$} & \multicolumn{2}{|c|}{$x_{1}\left(T,{ }^{\circ} \mathrm{C}\right)$} & \multicolumn{2}{|c|}{$x_{2}\left(t_{d}, \min \right)$} & \multicolumn{2}{|c|}{$x_{3}\left(M, \mathrm{~g} \cdot \mathrm{kg}^{-1}\right)$} & \multirow{2}{*}{$\begin{array}{l}Y_{2}\left(N_{1}\right) \\
22,0\end{array}$} & \multirow{2}{*}{$\begin{array}{l}Y_{3}\left(N_{2}\right) \\
21,0\end{array}$} \\
\hline & -1 & 30 & -1 & 120 & +1 & 400 & & \\
\hline 2 & +1 & 40 & -1 & 120 & -1 & 300 & 21,0 & 21,5 \\
\hline 3 & -1 & 30 & +1 & 180 & -1 & 300 & 22,0 & 22,0 \\
\hline 4 & +1 & 40 & +1 & 180 & +1 & 400 & 18,0 & 17,0 \\
\hline 5 & -1 & 30 & -1 & 120 & -1 & 300 & 23,0 & 22,0 \\
\hline 6 & +1 & 40 & -1 & 120 & +1 & 400 & 19,5 & 18,5 \\
\hline 7 & -1 & 30 & +1 & 180 & +1 & 400 & 21,0 & 21,5 \\
\hline 8 & +1 & 40 & +1 & 180 & -1 & 300 & 19,0 & 17,5 \\
\hline 9 & -1.215 & 29 & 0 & 150 & 0 & 350 & 21,5 & 22,5 \\
\hline 10 & +1.215 & 41 & 0 & 150 & 0 & 350 & 20,0 & 21,0 \\
\hline 11 & 0 & 35 & -1.215 & 114 & 0 & 350 & 21,0 & 20,5 \\
\hline 12 & 0 & 35 & +1.215 & 186 & 0 & 350 & 19,5 & 19,5 \\
\hline 13 & 0 & 35 & 0 & 150 & -1.215 & 290 & 20,0 & 21,0 \\
\hline 14 & 0 & 35 & 0 & 150 & +1.215 & 410 & 18,0 & 18,5 \\
\hline 15 & 0 & 35 & 0 & 150 & 0 & 350 & 20,0 & 20,0 \\
\hline
\end{tabular}


Table 3. Contents of ingredients of meals using food concentrates for first and second courses, $\mathrm{g} / 100 \mathrm{~g}$



*Ingredient developed in this work.

Amino acid composition of dried concentrates was determined with an amino acid analyzer AAA 400 (“INGOS”, Czech Republic, Prague), by GOST 32195 (2013).

Determination of moisture content in dried meat and food concentrates was performed by drying to a constant mass, following GOST 15113.4-77 (2002).

The determination of fat in dried meat and food concentrates was done by solvent extraction method according to GOST 15113.9-77 (2002).

The Kjeldahl method was used to determine protein in dried beef and food concentrates, following GOST 23327-98 (2011).

Carbohydrate content in dried meat and food concentrates was determined by the Bertrand method for the determination of soluble carbohydrates, by GOST 26176-91 (1993).

The determination of ash in dried meat and food concentrates followed GOST 15113.8-77 (2017).

$\beta$-carotene content was determined by a spectrophotometric method with samples being subjected to saponification with potassium hydroxide water - alcohol solution, vitamin extraction with diethyl ether, vitamin separation by chromatography on an aluminum oxide column, and quantitative determination of vitamins by photometric method (Sérino et al., 2009).

Ascorbic acid content was determined by titration, which is based on its reducing ability using Tillman's reagent (2,6-dichlorophenol-indophenol) as a specific reagent (Citovich, 1999). 
Organic acids content was expressed as malic acid content after total acidity determination by alkali titration method, according to GOST 15113.5-77 (2011).

Total mono- and disaccharides were determined by GOST 15113.6-77 (2003). The method is based on determining the bulk mass before the inversion of sugars (reducing sugars) and after inversion (the sum of sucrose, inverted sugar and reducing sugars) and their ability to recover a copper salt in an alkaline medium to copper oxide.

\section{Energy value evaluation}

Energy value was evaluated using Rubner coefficients: $4.1 \mathrm{kcal}$ are produced in the human body in the process of oxidizing $1 \mathrm{~g}$ of protein, $9.3 \mathrm{kcal}$ in the process of oxidizing $1 \mathrm{~g}$ of lipid, and $4.0 \mathrm{kcal}$ in the process of oxidizing $1 \mathrm{~g}$ of carbohydrates (Food..., 2002).

\section{Determination of the protein nutritional value}

The evaluation of the amino acid balance of the resulting products was determined according to the minimal score of essential amino acids $\left(C_{\min }\right.$; Mitchell and Block, 1946), which is based on the most limiting amino acid, and on the essential amino acids index (EAA) (Oser, 1959) compared to the standard of FAO (2011).

\section{Rheology analysis}

Rheological characteristics of the protein concentrates were evaluated by a modified method Veylera and Rebindera described by Machihin et al. (1982) in quadruplicate. Adhesion analysis was performed with the rheometer (model HR-2, Discovery Hybrid Rheometer, TA Instruments) at $25^{\circ} \mathrm{C}$ with the following parameters: touch force $F_{0}=0.5 \mathrm{~N}$, the stage moving speed $V=100 \mathrm{~mm} / \mathrm{min}$, the maximum force $F=7 \mathrm{~N}$, pause duration $\tau=30 \mathrm{~s}$. The adhesion was calculated from equation 1 :

where:

$$
F_{0}=\frac{F}{S}
$$

$$
\begin{aligned}
& F \text { - force separation, N, } \\
& S \text {-area disk, } \mathrm{m}^{2} .
\end{aligned}
$$

The plastic viscosity of the protein concentrates was determined using a viscometer RV-8 (VZ-4, Russia). Viscosity was estimated using equation 2 :

$$
\eta=\frac{K_{1} \cdot\left(P-P_{0}\right)}{n}
$$

where:

$P$ - load, rotating inner cylinder viscometer, $\mathrm{N}$,

$P_{0}-$ load, running to overcome friction in the bearings, $\mathrm{N}$,

$n$ - frequency rotation of the inner rotor, turnover/ $\min$,

$K_{1}-$ is a constant of the viscometer.

The value of the limit shear stress was calculated at the highest load $P_{\text {max }}$ according to equation 3 :

$$
\tau_{0}=\frac{P_{\max }}{S}
$$

where:

$P_{\text {max }}$ - the highest load, N,

$S^{\max }$ - the table area, $\mathrm{m}^{2}$.

\section{Sensory analysis}

The analyses of 5 organoleptic characteristics (appearance, color, odor, taste, and texture) were performed on the protein concentrates following GOST 15113.3-77 (2002). Sensory evaluations of the concentrates prepared from heart $\left(\mathrm{N}_{1}\right)$ and from liver $\left(\mathrm{N}_{2}\right)$ were carried out by 5 highly trained panelists (minimum number recommended for scoring tests (Kilcast, 2010)) on a 5 point scale for each of the 5 characteristics, with a maximum score of 25 points.

\section{Statistical analysis}

Analyses of the soybean ingredient, solution of tomato paste in milk whey, SPLC, protein concentrates and food concentrates were done in triplicate. Results were expressed as a mean with an indication of maximum standard deviation for the respective groups of results.

Statistical analysis was performed with Microsoft Excel (Microsoft, Redmond, Washington, USA). The influence of minced meat and SPLC ratio was tested by analysis of variance (one-way ANOVA). Tukey's multiple comparison tests were used to compare the groups of results. Statistical significance was considered at $p<0.05$ for all analyses (Zar, 1999).

To optimize the compression of the SPLC and the drying of the mixture of minced meat and SPLC, experiments were conducted by the standard matrix of 
a full factorial experiment for 15 experiments (Tables 1 and 2) with central and stellar points (Box and Draper, 1987). The matrix is written as $2^{3}$, where 3 is the number of factors varied during the experiment and 2 the number of levels. Estimation of the parameters of the regression equations of the second order was carried out using statistical analysis performed Minitab 17 Statistical Software (State College, PA).

\section{RESULTS AND DISCUSSION}

\section{Preparation of the SPLC}

Products of soybean in combination with products of animal origin can be successfully applied to improve the nutritional and biological value of food concentrates for diets in extreme conditions (Bojcova et al., 2011; Kalenik et al., 2012; Wayler et al., 1983). The results of numerous studies have shown that extraction from germinated soybean seeds is the most preferable option, from the standpoint of preparation and isolation of protein substances, due to the positive effects of germination on reduction of the content of anti-nutritional substances (trypsin inhibitors, the Bowman-Birk, urease), the increase in the content of mineral substances and vitamins and removal of the shell (Bau et al., 1997). The germination of soybean seeds in a saline aqueous medium until sprouts grow to a length of $20-30 \mathrm{~mm}$ allows the mineral content in the seeds to be increased, reduces the content of urease by $300-500 \mathrm{~g} \cdot \mathrm{kg}^{-1}$ and increases the content of ascorbic acid to $0.250 \mathrm{~g} \cdot \mathrm{kg}^{-1}$ in the soybean seeds (Petibskaja and Efremova, 2005).

Tomatoes and tomato products can also be successfully added to these products due to their low $\mathrm{pH}$, which is useful for the coagulation of soybean protein. As they are sources of lycopene, they are also known for their antioxidant properties. The human absorption of lycopene from tomato products is high, being, for example, higher than that from raw tomatoes (Shi, 2000), with the recommended mean dietary intake of lycopene being $25 \mathrm{mg}$ per day, with $500 \mathrm{~g} \cdot \mathrm{kg}^{-1}$ of lycopene being obtained from tomato products.

Milk whey is a protein-carbohydrate raw material obtained in the production of cottage cheese, cheese, and casein. Milk whey exceeds milk in utility. As well as the biological value of protein milk, which is higher for milk whey than for casein, it contains more than
200 vital nutrients and bioactive substances necessary for the full development and functioning of the human body (Brandelli et al., 2015). Milk whey contains magnesium, potassium, phosphorus from mineral substances and vitamins B, C, E, A, nicotinic acid, choline and biotin, and additionally, contains calcium chloride that, in combination with tomato paste, contributes to a better coagulation of soya protein.

To prepare SPLC, a suspension of soybean was mixed with tomato paste in milk whey, after which the process of the soybean protein settling occurs by its thermal and acid coagulation. First, an agglomeration of colored protein particles was observed, which then settled. It was found that the mass of the produced protein particles depends on the $\mathrm{pH}$ of the liquid fraction, on the dry matter content of the tomato paste solution and the temperature of the dispersion medium. As a result of this process, two products, namely SPLC and soybean-milk whey, both pink in color, were produced.

SPLC was then mixed with minced meat. To effectively mix it, SPLC must be pressed to a moisture level identical to that of minced meat, to ensure uniform mixing and distribution of nutrients. SPLC has a smooth paste-like consistency, so increasing the pressing pressure leads to clogging of the press holes, resulting in loss of clot and making it difficult for the liquid to drain. Reducing the pressing pressure slows down the process, leading to drying of the surface layer, which adversely affects the quality of the coagulum. Together with pressing pressure $(P)$, the initial humidity of the SPLC $\left(W_{i}\right)$ and pressing time $\left(t_{p}\right)$ significantly affect the final humidity of the $\operatorname{SPLC}(W)$. These parameters were optimized by response surface methodology.

The mathematical model for pressing the liquid fraction from the colored SPLC, obtained from the results presented in Table 1 , is presented in equation 4 (coefficients with $p<0.05$ ).

$$
\begin{gathered}
W_{f}=205.6-3.85 \cdot W_{i}-45.9 \cdot P+0.142 \cdot t_{p}+ \\
+0.00288 \cdot W_{i}^{2}+10.07 \cdot P^{2}
\end{gathered}
$$

The optimum combination of factors in which $W_{f}$ is a minimum is: initial humidity of the colored SPLC of $658 \mathrm{~g} \cdot \mathrm{kg}^{-1}$; squeeze pressure of $1.49 \mathrm{MPa}$ and 31 
Table 4. Main nutrients and amino acid composition of the initial ingredients and the SPLC at optimum processing conditions $(n=3$; average values with standard deviation being less than 0.5$)$

\begin{tabular}{|c|c|c|c|}
\hline \multirow{2}{*}{ Nutrients } & \multicolumn{3}{|c|}{ Product } \\
\hline & soybean ingredient & tomato paste in milk whey & SPLC \\
\hline Water, $\mathrm{g} \cdot \mathrm{kg}^{-1}$ & 875 & 850 & 474 \\
\hline Protein, $\mathrm{g} \cdot \mathrm{kg}^{-1}$ & 38 & 28 & 371 \\
\hline Lipids, $\mathrm{g} \cdot \mathrm{kg}^{-1}$ & 22 & 01 & 55 \\
\hline Carbohydrates, $\mathrm{g} \cdot \mathrm{kg}^{-1}$ & 42 & 120 & 55 \\
\hline Fiber, $\mathrm{g} \cdot \mathrm{kg}^{-1}$ & 5 & 7 & 15 \\
\hline Ash, $\mathrm{g} \cdot \mathrm{kg}^{-1}$ & 23 & 16 & 30 \\
\hline Ascorbic acid, $\mathrm{mg} \cdot \mathrm{kg}^{-1}$ & 55 & 250 & 100 \\
\hline Organic acids (expressed as malic acid), $\mathrm{mg} \cdot \mathrm{kg}^{-1}$ & - & 15 & 5 \\
\hline$\beta$-carotene, $\mathrm{mg} \cdot \mathrm{kg}^{-1}$ & - & 10 & 25 \\
\hline
\end{tabular}

min of pressing time. The optimum pressure and time were closest to the maximum values studied, while the initial water content was closest to the minimum. This means that higher initial water contents will require longer times to drain the coagulum, since pressure should be maintained close to $1.5 \mathrm{MPa}$ to avoid clogging.

The nutrient composition of the soybean ingredient, tomato paste in milk whey and SPLC prepared with optimized conditions are shown in Table 4. Decreasing the water content of the SPLC to $474 \mathrm{~g} \cdot \mathrm{kg}^{-1}$ allowed the level of proteins to increase to $371 \mathrm{~g} \cdot \mathrm{kg}^{-1}$, along with the contents of lipids, fiber, ash, $\beta$-carotene and ascorbic acid, which make them richer in nutrients for nutrition in extreme conditions requiring a high density of macro and micronutrients (Marriott and Carlson, 1996).

\section{Preparation of the minced meat}

Minced meat from beef by-products, heart and liver, were prepared to mix with SPLC. Moisture content should be minimized to obtain dried minced meat, to enable energy to be saved in the drying step after mixing with SPLC. The tests conducted showed that the moisture content of the by-products decreased compared to the raw material by $250-280 \mathrm{~g} \cdot \mathrm{kg}^{-1}$, depending on the type of by-product, as the result of blanching followed by drainage.

\section{Preparation of the protein concentrate} The effect of the proportion of minced meat and SPLC on rheological properties. A protein concentrate was prepared by mixing minced meat and SPLC. The final steps of the technological scheme for producing the protein concentrate are shown at the bottom of Figure 1. The SPLC product was mixed with minced meat by-products, granules were formed and then dried. SPLC acts as a thickener for the composition (increases its water retention capacity) and improves the minced meat organoleptic indicators, such as color and taste. In addition, it provides a balanced chemical composition of the finished product regarding protein, lipid and carbohydrate content and enriches it with other nutrients (Table 4).

Minced meat and SPLC were mixed in ratios of 90:10, 70:30, and 50:50 and its rheological characteristics were determined (Table 5). Data analysis showed that an increase of the SPLC component from $100 \mathrm{~g} \cdot \mathrm{kg}^{-1}$ to $500 \mathrm{~g} \cdot \mathrm{kg}^{-1}$ results significantly ( $p$ $<0.05)$ in a decrease of the shear stress limit, with values of 9.3 and $11.4 \mathrm{~Pa} \cdot \mathrm{s}$ respectively for beef heart-based minced meat and beef liver-based minced meat. Adhesiveness changes similarly to shear stress while plastic viscosity does not present a significant similar tendency. All the observed changes facilitated the moulding process, and at the same time the finished concentrate had a more attractive appearance, 
Table 5. Rheological characteristics of protein concentrates prepared with different proportions of minced meat and SPLC $(n=4)$

\begin{tabular}{lcccccc}
\hline \multirow{2}{*}{ Rheological characteristic } & \multicolumn{3}{c}{ Minced meat based beef heart } & \multicolumn{3}{c}{ Minced meat based beef liver } \\
\cline { 2 - 6 } & $90: 10$ & $70: 30$ & $50: 50$ & $90: 10$ & $70: 30$ & $50: 50$ \\
\hline Limit shear stress, $\mathrm{Pa}$ & $17.4 \pm 1.2^{\mathrm{a}}$ & $15.8 \pm 1.3^{\mathrm{ab}}$ & $9.3 \pm 0.7^{\mathrm{c}}$ & $16.6 \pm 1.1^{\mathrm{ab}}$ & $14.2 \pm 1.3^{\mathrm{b}}$ & $11.4 \pm 0.7^{\mathrm{c}}$ \\
Plastic viscosity, Pas & $24.2 \pm 0.7^{\mathrm{c}}$ & $25.6 \pm 0.9^{\mathrm{bc}}$ & $24.4 \pm 0.5^{\mathrm{cd}}$ & $29.1 \pm 0.9^{\mathrm{a}}$ & $26.5 \pm 1.2^{\mathrm{bd}}$ & $25.4 \pm 1.1^{\mathrm{bcd}}$ \\
Adhesiveness (or stickiness, & $2.2 \pm 0.09^{\mathrm{b}}$ & $2.1 \pm 0.07^{\mathrm{bc}}$ & $1.9 \pm 0.05^{\mathrm{c}}$ & $2.6 \pm 0.13^{\mathrm{a}}$ & $2.3 \pm 0.1^{\mathrm{b}}$ & $2.1 \pm 0.1^{\mathrm{bc}}$ \\
$10^{3} \mathrm{~Pa}$ ) & & & & & &
\end{tabular}

For each parameter, different lowercase superscript letters indicate significant differences $(p<0.05)$.

was more flexible, with more uniform water saturation, and the dried product absorbed water faster. However, the replacement of more than $50 \%$ of the meat raw materials by vegetable matter gave samples an excessively loose consistency and low strength characteristics, preventing moulding. With the addition of coagulum in a smaller proportion, the mixture presented a high moisture and liquid consistency, as well as a specific meat taste.

Optimization of the drying step. To create food concentrate recipes which are appropriate for the first and second courses of the same meal, the protein concentrate should be dried in such a way to maximally prevent the loss of nutrients, providing the best possible good organoleptic properties. Therefore, the organoleptic characteristics $\left(N_{i}\right)$ of the final product, which are dependent on factors such as drying temperature $(T)$, drying duration $\left(t_{d}\right)$, and the mass fraction of the colored SPLC $(M)$, were optimized.

$N_{l}$ is the organoleptic evaluation of the heart-based concentrate, and $N_{2}$ is the organoleptic evaluation of the liver-based concentrate. From the results of the experiments (Table 2), the mathematical models that resulted from drying of the protein concentrates are presented in equations 5 (coefficients with $p<0.1$ ) and 6 (all coefficients):

$$
\begin{gathered}
N_{1}=65.3-2.35 \cdot T-0.164 \cdot t_{d}+0.0897 \cdot M+ \\
\quad+0.0343 \cdot T^{2}+0.00568 \cdot t_{d}^{2} \\
N_{2}=7.6-1.30 \cdot T+0.219 \cdot t_{d}+0.158 \cdot M+ \\
-0.0500 \cdot T \cdot t_{d}-0.00100 \cdot T \cdot M+0.00250 \cdot t_{d} \cdot M+ \\
\quad+0.0306 \cdot T^{2}-0.00500 \cdot t_{d}^{2}-0.000250 \cdot M^{2}
\end{gathered}
$$

Optimal values of organoleptic evaluation $\left(N_{1}\right.$ and $N_{2}$ ) are in the range $23.7-23.2$ points (25 point scale), and optimum parameters calculated from these equations are, respectively: drying temperature of $29^{\circ} \mathrm{C}$; drying duration of $114 \mathrm{~min}$ and $157.6 \mathrm{~min}$; mass fraction of the colored SPLC of $306 \mathrm{~g} \cdot \mathrm{kg}^{-1}$ and $336 \mathrm{~g} \cdot \mathrm{kg}^{-1}$. These results show a direct correlation between drying time and SPLC: the higher the SPLC content, the longer the drying time.

Increasing the drying temperature shortens the drying time, but increases the heat costs and increases the destruction of amino acids and vitamins, and there is a risk of excessive drying of the concentrate, which also affects the taste. Thus, it was expected that an optimum temperature would be obtained close to the minimum temperature studied.

When temperature decreases, drying time needs to be increased. The established duration of granule drying ensures an even distribution of moisture throughout the whole mass, preventing over-drying and burning of the surface, as well as achieving the required humidity.

Nutritional evaluation of the protein concentrates. The chemical composition and energy value of the final products prepared by the first category of byproducts, beef heart and liver prepared with a minced meat and SPLC ratio of 70:30, are shown in Table 6 . Prepared protein concentrates are characterized by a high calorific value of $376 \mathrm{kcal} / 100 \mathrm{~g}$ of dry product, with protein being its major nutrient, constituting 641-644 $\mathrm{g} \cdot \mathrm{kg}^{-1}$.

Protein is an essential component of food concentrates. Protein from minced meat with SPLC contains all exogenous amino acids (Table 7) at high levels. The EEA index is 100 for both concentrates, with the 
Kalenik, T. K., Costa, R., Motkina, E. V., Kosenko, T. A., Skripko, O. V., Kadnikova, I. A. (2017). Technological development of protein-rich concentrates using soybean and meat by-products for nutrition in extreme conditions. Acta Sci. Pol. Technol. Aliment., 16(3), 255-268. http://dx.doi.org/10.17306/J.AFS.2017.0501

Table 6. Chemical composition and energy value of the protein concentrates prepared with a minced meat and SPLC ratio of 70:30 ( $n=3$; average values with standard deviation being less than 0.5$)$

\begin{tabular}{lcccccccc}
\hline $\begin{array}{c}\text { Protein concen- } \\
\text { trate based }\end{array}$ & water & protein & fat & carbohydrates & fiber & ash & organic acids & $\begin{array}{c}\text { Energy value } \\
\mathrm{kcal} / 100 \mathrm{~g}\end{array}$ \\
\cline { 2 - 8 } Heart & 98 & 641 & 87 & 58 & 42 & 74 & 4.0 & 376.1 \\
Liver & 98 & 644 & 88 & 56 & 39 & 75 & 3.8 & 376.2 \\
\hline
\end{tabular}

Table 7. Essential amino acid composition of the protein concentrates (average values are presented with standard deviation being less than 0.5 )

\begin{tabular}{|c|c|c|c|c|c|c|c|c|c|c|}
\hline \multirow[b]{2}{*}{ Product } & \multicolumn{8}{|c|}{ Essential amino acid, $\mathrm{g} \cdot \mathrm{kg}^{-1}$} & \multirow[b]{2}{*}{$\begin{array}{l}\text { EAA } \\
\text { index }\end{array}$} & \multirow[b]{2}{*}{$\mathrm{C}_{\text {min }}, \%$} \\
\hline & valine & $\begin{array}{l}\text { isoleu- } \\
\text { cine }\end{array}$ & leucine & lysine & $\begin{array}{c}\text { methio- } \\
\text { nine }+ \\
\text { cysteine }\end{array}$ & threonine & $\begin{array}{l}\text { trypto- } \\
\text { phan }\end{array}$ & $\begin{array}{c}\text { phenyla- } \\
\text { lanine } \\
+ \\
\text { tyrosine }\end{array}$ & & \\
\hline $\begin{array}{l}\text { FAO standard } \\
\text { (FAO, 2011) }\end{array}$ & 40 & 30 & 61 & 48 & 23 & 25 & 6.6 & 60 & & 100 \\
\hline Beef liver based & 62 & 48 & 82 & 71 & 36 & 41 & 13.0 & 85 & 100 & 128 \\
\hline Beef heart based & 57 & 47 & 90 & 74 & 32 & 40 & 11.7 & 60 & 100 & 100 \\
\hline
\end{tabular}

minimum essential amino acid content of these protein concentrates constituting $100-128 \%$ of the FAO standard, depending on the raw meat material used. The comparison of essential amino acid contents with the standard protein stipulated by FAO shows that leucine in beef liver-based concentrate and aromatic amino acids in the beef heart-based concentrate are the lowest, but with a content which is still higher than the standard.

Besides protein, these products contain $87-88 \mathrm{~g} \cdot \mathrm{kg}^{-1}$ of fat, $56-58 \mathrm{~g} \cdot \mathrm{kg}^{-1}$ of carbohydrates, $39-42 \mathrm{~g} \cdot \mathrm{kg}^{-1}$ of fibre and $74-75 \mathrm{~g} \cdot \mathrm{kg}^{-1}$ of ash.

Due to the high content of protein, low fat and carbohydrates, and high calorific value, it should be considered that this product meets the requirements for multicomponent foods. Usually, a mixture of these nutrients requires different ingredients, such as canned or dried meat and vegetables.

The water content of the obtained protein concentrates is $98 \mathrm{~g} \cdot \mathrm{kg}^{-1}$. When compared to other products mainly composed of proteins and with no sugars, this value assures a water activity much lower than 0.85 (Schmidt and Fontana, 2008), which gives the product a long shelf life when adequately packaged.

\section{Food concentrate development}

The developed protein concentrates were used in the recipes of food concentrates for the first and second courses (Table 3), respecting the general requirements (rations) applicable to food products in extreme conditions (FSB, 2011).

The results of the chemical composition analysis and energy values of the food concentrates are shown in Table 8. Dinner dishes prepared from these food concentrates are high-calorie foodstuffs, with energy values varying from $370.5-380.5 \mathrm{kcal} / 100 \mathrm{~g}$ product. Analysis of the data indicates that the soups with heartbased minced meat contain $150-178 \mathrm{~g} \cdot \mathrm{kg}^{-1}$ protein, $100 \mathrm{~g} \cdot \mathrm{kg}^{-1}$ fat and $88-93 \mathrm{~g} \cdot \mathrm{kg}^{-1}$ ash. The content of vitamin $C$ in the soups varies from 23 to $25 \mathrm{mg} \cdot \mathrm{kg}^{-1}$ and of $\beta$-carotene ranges from $40-49 \mathrm{mg} \cdot \mathrm{kg}^{-1}$. Porridges with liver-based minced meat contain $135-175 \mathrm{~g} \cdot \mathrm{kg}^{-1}$ of complementary protein, $65 \mathrm{~g} \cdot \mathrm{kg}^{-1}$ of fat and $30-36$ $\mathrm{mg} \cdot \mathrm{kg}^{-1}$ of $\beta$-carotene. Tomato paste, liver and carrots are the sources of $\beta$-carotene in these food concentrates for the different porridges, and contribute to contents of $\beta$-carotene from $1.025-1.25 \mathrm{mg} \cdot 100 \mathrm{~g}^{-1}$ in ready-touse products by a ratio of $1: 3$ (concentrate:water), that is $25.6-31.2 \%$ of the recommended daily intake (Biesalski et al., 1997). These products can be classified as functional according to GOST R 52349-2005 (2008) because they contain functional ingredients such as lycopene, essential amino acids, vitamin E (from soya) and soya fatty acids. 
Table 8. Estimation of the chemical composition and energy value of the food concentrates prepared with the protein concentrates

\begin{tabular}{|c|c|c|c|c|c|c|c|c|c|c|}
\hline \multirow[b]{2}{*}{ Concentrate } & \multicolumn{9}{|c|}{ Chemical composition, $\mathrm{g} \cdot \mathrm{kg}^{-1}$} & \multirow{2}{*}{$\begin{array}{l}\text { Energy value } \\
\mathrm{kcal} / 100 \mathrm{~g}\end{array}$} \\
\hline & water & protein & fat & $\begin{array}{c}\text { mono- and } \\
\text { disaccharides }\end{array}$ & starch & fiber & ash & $\begin{array}{c}\text { ascorbic acid } \\
\mathrm{mg} \cdot \mathrm{kg}^{-1}\end{array}$ & $\beta$-carotene & \\
\hline \multicolumn{11}{|c|}{ Soups with heart-based protein concentrate } \\
\hline Buckwheat & 90 & 178 & 100 & 50 & 466 & 23 & 93 & 25 & 49 & 376.8 \\
\hline Rice & 90 & 150 & 100 & 65 & 475 & 28 & 92 & 23 & 40 & 377.2 \\
\hline Pearl barley & 90 & 162 & 100 & 37 & 494 & 28 & 89 & 24 & 43 & 378.8 \\
\hline Oatmeal & 90 & 170 & 100 & 66 & 461 & 25 & 88 & 25 & 41 & 378.4 \\
\hline \multicolumn{11}{|c|}{ Porridges with liver-based protein concentrate } \\
\hline Buckwheat & 90 & 175 & 65 & 25 & 580 & 10 & 55 & 21 & 36 & 370.5 \\
\hline Rice & 90 & 135 & 65 & 18 & 640 & 11 & 41 & 23 & 30 & 380.5 \\
\hline Pearl barley & 90 & 150 & 65 & 22 & 599 & 12 & 42 & 20 & 32 & 371.7 \\
\hline Oatmeal & 90 & 165 & 65 & 19 & 606 & 10 & 45 & 21 & 31 & 378.5 \\
\hline
\end{tabular}

\section{CONCLUSIONS}

In this work, the technology for the mixture of minced meat with a soybean component was successfully developed. The technological approaches to the production of the meat component, the colored SPLC with the required moisture content, and the mixing process, have been found and defined by mathematical modeling.

The results of the comparison of the amino acid compositions of the protein concentrates with the standard protein by the FAO, and the presence of functional nutrients demonstrate that these concentrates are biologically valuable products.

The use of $160 \mathrm{~g}$ of concentrates for the preparation of the first and the second courses will meet the daily average energy need of $2500 \mathrm{kcal}$ per day, and the use of $250 \mathrm{~g}$ would cover the average daily energy needs of different groups of the military $(3850 \mathrm{kcal}$ per day) (Skurihina and Tuteljana, 2002). This type of product will expand the range of food concentrates for nutrition in extreme conditions.

\section{ACKNOWLEDGEMENTS}

The authors extend their appreciation to Vladimir A. Tilba, Dr. Biol. Sc., Professor of the Russian Academy of Agricultural Sciences, Director of the State Budgetary Scientific Institution "Russian Research Institute for Soya" and to Sergey M. Dotsenko, Dr. Tech. Sc., Professor, Director of the laboratory for the technology of agricultural product processing of the State Budgetary Scientific Institution "Russian Research Institute for Soya" for their assistance in arranging the study. This work was supported by the Russian Science Foundation (Project 14-50-00034).

\section{REFERENCES}

Bau, H., Villaume, C., Nicolas, J.-P., Mejean, L. (1997). Effect of germination on chemical composition, biochemical constituents and antinutritional factors of soya bean (Glycine max) seeds. J. Sci. Food Agric., 73, 1-9. http:// doi.org/10.1002/(SICI)1097-0010(199701)73:1<1:: AID-JSFA694>3.0.CO;2-B

Berdanier, C. D., Dwyer, J. T., Heber, D. (2013). Handbook of nutrition and food Boca Raton: CRC Press Book.

Biesalski, H. K., Böhles, H., Esterbauer, H., Fürst, P., Gey, F., Hundsdörfer, G., ..., Weisburger, J. (1997). Antioxidant vitamins in prevention. Clin. Nutr., 16(3), 151-155. https://doi.org/10.1016/S0261-5614(97)80245-2

Bojcova, T. M., Kalenik, T. K., Rjapisov, D. V., Docenko, S. M., Skripko, O. V. (2011). Razrabotka tehnologij molochno-rastitelnyh produktov pitanija [Development of dairy and vegetable food technologies]. Pishhev. Promyshl., 3, 12-14 [in Russian].

Box, G. E. P., Draper, N. R. (1987). Empirical model-building and response surfaces. Wiley Series in Probability and Mathematical Statistics. New York: Wiley. 
Kalenik, T. K., Costa, R., Motkina, E. V., Kosenko, T. A., Skripko, O. V., Kadnikova, I. A. (2017). Technological development of protein-rich concentrates using soybean and meat by-products for nutrition in extreme conditions. Acta Sci. Pol. Technol. Aliment., 16(3), 255-268. http://dx.doi.org/10.17306/J.AFS.2017.0501

Brandelli, A., Daroit, D. J., Corrêa, A. P. F. (2015). Whey as a source of peptides with remarkable biological activities. Food Res. Int., 73, 149-161. http://doi.org/10.1016/j. foodres.2015.01.016

Citovich, I. K. (1999). Analiticheskaja himija [Analytical chemistry]. Moskva: Kolos [in Russian].

FAO (2011). Dietary protein quality evaluation in human nutrition. Food and Agriculrure Organization of the United Nations. New York: Academic Press. Retrieved from http://www.nutrinfo.com/biblioteca/libros_digitales/fao_protein_quality.pdf

Flandrin, J.-L., Montanari, M. (Eds.). (1999). Food: A culinary history from antiquity to the present. Columbia: Columbia Univ. Press.

Food Standards Agency. (2002). McCance and Widdowson's The Composition of Foods (sixth edition). Cambridge: Royal Society of Chemistry.

FSB (2011). N 55 “Ob ustanovlenii norm pajkov, racionov pitanija i komplektov avarijnogo zapasa, norm obespechenija kormami (produktami) shtatnyh zhivotnyh, norm zameny odnih produktov drugimi i norm obespechenija podstilochnymi materialam [On the establishment of norms for rations, rations and emergency stock sets, norms for ensuring the food (products) of standard animals, the norms for the replacement of certain products by others, and the norms for providing litter materials]. Retrieved from http://base.garant. $\mathrm{ru} / 55171131 / \#$ ixzz4KnfO4Xzi

GOST 15113.3-77 (2002). Koncentraty pishhevye. Metody opredelenija organolepticheskih pokazatelej, gotovnosti koncentratov k upotrebleniju i ocenki dispersnosti suspenzii [Food concentrates: Methods for determination of organoleptic parameters, readiness of concentrates for use and evaluation of dispersity of suspension]. Federal'noe agentstvo po tehnicheskomu regulirovaniju i metrologii, Rossijskaja Federacija [in Russian]. Retrieved from http://standartgost.ru/g/ГOCT_15113.3-77

GOST 15113.4-77 (2002). Koncentraty pishhevye. Metody opredelenija vlagi [Food concentrates: Methods for determination of moisture]. Federal'noe agentstvo po tehnicheskomu regulirovaniju i metrologii, Rossijskaja Federacija [in Russian]. Retrieved from http://standartgost.ru/g/ГOCТ_15113.4-77

GOST 15113.5-77 (2011). Koncentraty pishhevye. Metody opredelenija kislotnosti (s Izmeneniem N 1) [Food concentrates: Methods for determination of acidity]. Federal'noe agentstvo po tehnicheskomu regulirovaniju i metrologii, Rossijskaja Federacija [in Russian]. Retrieved from http://docs.cntd.ru/document/ gost-15113-5-77

GOST 15113.6-77 (2003). Koncentraty pishhevye. Metody opredelenija saharozy [Food concentrates: Methods for determination of sucrose]. Federal'noe agentstvo po tehnicheskomu regulirovaniju i metrologii, Rossijskaja Federacija [in Russian]. Retrieved from http://www. internet-law.ru/gosts/gost/33058

GOST 15113.8-77 (2017). Koncentraty pishhevye. Metody opredelenija zoly [Food concentrates: Methods for determination of ash]. Federal'noe agentstvo po tehnicheskomu regulirovaniju i metrologii, Rossijskaja Federacija [in Russian]. Retrieved from http://www. internet-law.ru/gosts/gost/24954/

GOST 15113.9-77 (2002). Koncentraty pishhevye. Metody opredelenija zhira [Food concentrates: Methods for determination of fat]. Federal'noe agentstvo po tehnicheskomu regulirovaniju i metrologii, Rossijskaja Federacija [in Russian]. Retrieved from http://standartgost. $\mathrm{ru} / \mathrm{g} /$ ГОCТ_15113.9-77

GOST 17109-88 (1995). Soja. Trebovanija pri zagotovkah i postavkah [Soy-beans: Requirements for state purchases and deliveries]. Federal'noe agentstvo po tehnicheskomu regulirovaniju i metrologii, Rossijskaja Federacija [in Russian]. Retrieved from http://standartgost. $\mathrm{ru} / \mathrm{g} /$ ГОСТ_17109-88

GOST 23327-98 (2011). Moloko i molochnye produkty. Metod izmerenija massovoj doli obshhego azota po K'el'dalju i opredelenie massovoj doli belka [Milk and milk products: Determination of total nitrogen by the Kjeldahl method and determination of total protein]. Federal'noe agentstvo po tehnicheskomu regulirovaniju i metrologii, Rossijskaja Federacija [in Russian]. Retrieved from http://standartgost.ru/g/ГОСТ_23327-98

GOST 26176-91 (1993). Korma, kombikorma. Metody opredelenija rastvorimyh i legkogidrolizuemyh uglevodov [Fodders, mixed feeds: Methods for determination of soluble and hydrolysable carbohydrates]. Federal'noe agentstvo po tehnicheskomu regulirovaniju i metrologii, Rossijskaja Federacija [in Russian]. Retrieved from http://standartgost.ru/g/ГОСТ 26176-91

GOST 32195 (2013). Korma, kombikorma. Metod opredelenija soderzhanija aminokislot [(ISO 13903: 2005)Forage, feed: Method of determination of amino acids]. Federal'noe agentstvo po tehnicheskomu regulirovaniju i metrologii, Rossijskaja Federacija [in Russian]. Retrieved from http://standartgost.ru/g/ГOCТ_32195-2013

GOST 32244 (2013). Subprodukty mjasnye obrabotannye. Tehnicheskie uslovija [Processed meat by-products. Specification]. Federal'noe agentstvo po tehnicheskomu regulirovaniju i metrologii, Rossijskaja Federacija [in Russian]. Retrieved from http://standartgost.ru/g/ ГОСТ 32244-2013

GOST 3343-89 (2008). Produkty tomatnye koncentrirovannye. Obshhie tehnicheskie uslovija [Concentrated tomato products. General specifications]. Federal'noe 
agentstvo po tehnicheskomu regulirovaniju i metrologii, Rossijskaja Federacija [in Russian]. Retrieved from http://standartgost.ru/g/ГOCT_3343-89

GOST R 52349-2005 (2008). Produkty pishhevye. Produkty pishhevye funkcional'nye. Terminy i opredelenija [Foodstuffs: Functional foods - Terms and definitions]. Federal'noe agentstvo po tehnicheskomu regulirovaniju i metrologii, Rossijskaja Federacija [in Russian]. Retrieved from http://standartgost.ru/g/ ГOCT_P_52349-2005

GOST R 53438 (2009). Syvorotka molochnaja. Tehnicheskie uslovija [Whey specifications]. Federal'noe agentstvo po tehnicheskomu regulirovaniju i metrologii, Rossijskaja Federacija [in Russian]. Retrieved from http:// standartgost.ru/g/ГOCT_P_53438-2009

GOST R 53600 (2009). Semena maslichnye, zhmyhi i shroty. Opredelenie vlagi, zhira, proteina i kletchatki metodom spektroskopii v blizhnej infrakrasnoj oblasti [Oilseeds, oilcakes and oilmeals: Determination of moisture, fat, protein and fiber by near infrared spectroscopy]. Federal'noe agentstvo po tehnicheskomu regulirovaniju i metrologii, Rossijskaja Federacija [in Russian]. Retrieved from http://standartgost.ru/g/ ГОСТ P 53600-2009

Holt, S. H., Miller, J. C., Petocz, P., Farmakalidis, E. (1995). A satiety index of common foods. Eur. J. Clin. Nutr., 49(9), 675-690. Retrieved from

https://www.ncbi.nlm.nih.gov/pubmed/7498104?dopt=Abs tract\&holding $=$ npg

JAWAFOOD. (n.d.). Food in extreme conditions. Retrieved December 26, 2015, from http://rww.myjino.ru/ extremefood/index en.htm

Kalenik, T. K., Docenko, S. M., Kupchak, D. V. (2012). Optimizacija receptury i razrabotka tehnologii vesovyh pashtetov s soevo-ovoshhnym produktom [Optimization of the recipe and the technology development for weight pastes with a soybean and vegetable product]. Pishhev. Promyshl., 6, 32-33 [in Russian].

Kilcast, D. (Ed.). (2010). Sensory analysis for food and beverage quality control. Cambridge: Woodhead Publ.

Machihin, S. A., Maslov, A. M., Tabachnikov, V. P., Machihin, J. A., Kosoj, V. D. (1982). Strukturnyye i mekhanicheskiye svoystva pishchevykh produktov [Structural and mechanical properties of foods]. In Ljogkaja i pishhevaja promyshlennost' (p. 296) [in Russian]

Marriott, B. M., Carlson, S. J. (1996). nutritional needs in cold and high-altitude environments: Applications for military personnel in field operations (Vol. 584). National Academies Press. Retrieved from http://www.nap. edu/catalog/5197.html

Mitchell, H. H., Block, R. J. (1946). Some relationships between the amino acid contents of proteins and their nutritive values for the rat. J. Biol. Chem., 163, 599-620. Retrieved from http://www.jbc.org/content/163/3/599. full.pdf?sid=24cb1b19-67e7-4881-bea1-958ddc 842540

Oser, B. L. (1959). An integrated essential amino acid index for predicting the biological value of proteins. In A. A. Albanese (Ed.), Protein and amino acid nutrition (pp. 281-295). Academic Press. https://doi.org/10.1016/ B978-0-12-395683-5.50014-6

Petibskaja, V. S., Efremova, E. G. (2005). Pitatel'naja cennost' soevyh prorostkov [The nutritional value of soybean seedlings]. Food Technol., 1, 36-39 [in Russian].

Poos, M. I., Costello, R., Carlson-Newberry, S. J. (1999). Committee on military nutrition research. Washington: National Academy Press.

Schmidt, S. J., Fontana, A. J. (2008). Water activity in foods: Fundamentals and applications. In G. V. Barbosa-Cánovas, A. J. Fontana, S. J. Schmidt, T. P. Labuza (Eds.), Water activity in foods (pp. 407-420). Oxford, UK: Blackwell Publ. https://doi.org/10.1002/9780470376454.app5

Selvamurthy, W., Singh, S. N. S. (2003). Nutritional requirements for human adaptation in extreme environments. Proceedings of the Indian National Science Academy Part B. Rev. Tracts Biol. Sci., 69(4), 485-505.

Sérino, S., Gomez, L., Costagliola, G. U. Y., Gautier, H. (2009). HPLC assay of tomato carotenoids: Validation of a rapid microextraction technique. J. Agric. Food Chem., 57, 8753-8760. https://doi.org/10.1021/ jf902113n

Shi, J. (2000). Lycopene in tomatoes: Chemical and physical properties affected by food processing. Crit. Rev. Biotechn., 20(4), 293-334. http://doi.org/10.1080/07388550091144212

Skurihina, I. M., Tuteljana, V. A. (2002). Himicheskij sostav rossijskih pishhevyh produktov: Spravochnik [Chemical composition of Russian food products: Reference book]. Moskva: Deli Print.

Srivastava, K. K., Kumar, R., Sciences, A. (1992). Human nutrition in cold and high terrestrial altitudes. Int. J. Biometeorol., 36(1), 10-13. https://doi.org/10.1007/ BF01208728

Standarty Rossijskoj Federacii. (2016). Retrieved from http://standartgost.ru/

UD6-81-3E. (2011). UD 6-81-3E Instruction in Winter Service - Nutrition in Cold Conditions. Retrieved from https://forsvaret.no/en/ForsvaretDocuments/1 UD6-81-1E WINTER CONDITIONS LEADERSHIP AND TRAINING 2013.pdf

Zar, J. H. (1999). Biostatistical Analysis. Prentice Hall.

Wayler, A., Queiroz, E., Scrimshaw, N. S., Steinke, F. H., Rand, W. M., Young, V. R. (1983). Nitrogen balance studies in young men to assess the protein quality of an isolated soy protein in relation to meat proteins. J. Nutr., 113(12), 485-491. 